Levinas AND The Night of Being 
This page intentionally left blank 


\title{
Levinas and the Night of Being
}

A Guide to Totality and INFINITY

\author{
Raoul Moati \\ Translated by Daniel Wyche
}

F O R D H A M U I VERS I T Y P RES S

New York 2017 


\section{Copyright (C) 2017 Fordham University Press}

All rights reserved. No part of this publication may be reproduced, stored in a retrieval system, or transmitted in any form or by any means-electronic, mechanical, photocopy, recording, or any other-except for brief quotations in printed reviews, without the prior permission of the publisher.

This book was first published in French as Événements nocturnes: Essai sur "Totalité et infini," by Raoul Moati (c) Éditions Hermann, 2012.

This book's publication was supported by a subvention from the University of Chicago's Visiting Committee to the Division of Humanities.

Fordham University Press has no responsibility for the persistence or accuracy of URLs for external or third-party Internet websites referred to in this publication and does not guarantee that any content on such websites is, or will remain, accurate or appropriate.

Fordham University Press also publishes its books in a variety of electronic formats. Some content that appears in print may not be available in electronic books.

Visit us online at www.fordhampress.com.

Library of Congress Cataloging-in-Publication Data is available online at http://catalog.loc.gov.

Printed in the United States of America

$\begin{array}{llllllll}\text { I9 } & \text { I } 8 & \text { I } 7 & 5 & 4 & 3 & 2 & \text { I }\end{array}$

First edition 